\title{
MOLECULAR APPROACH TO UNCOVER THE FUNCTION OF BACTERIA IN PETROCHEMICAL REFINING WASTEWATER: A MINI REVIEW
}

\author{
UgYa, A. Y. ${ }^{1,2}-$ HUA, $X^{1}-$ AgAmuthu, P. ${ }^{3}-$ MA, J..$^{*}$ \\ ${ }^{1}$ College of New Energy and Environment, Jilin University, 130012 Changchun, China \\ ${ }^{2}$ Department of Environmental Management, Kaduna State University, Kaduna, Nigeria \\ ${ }^{3}$ Institute of Biological Sciences, Faculty of Sciences, University of Malaya, Kuala Lumpur, Malaysia \\ *Corresponding author \\ e-mail: jincaima@jlu.edu.cn (Dr/ProfessorJincai Ma)
}

(Received $16^{\text {th }}$ Dec 2018; accepted $12^{\text {th }}$ Feb 2019)

\begin{abstract}
Water is one of the most important resources in the universe. This is due to the fact that all life processes require the use of water. The rate at which petrochemical refineries release wastewater is alarming, and needs to be stoped. Many attempts to improve the efficiency of treatment methods of petrochemical refining wastewater have been made, among which bioremediation is considered an emerging advancement. Bioremediation incentivized the identification and characterization of most bacteria responsible for the breakdown of petrochemical refinery wastewater pollutants. The use of genomic approach (DNA and RNA sequence) in the identification of these bacteria is widely accepted. However, proteins and metabolites as functional entities in a cell are gaining less attention but could still be used to give an accurate insight into how Bacteria respond to pollutants in refinery wastewater. This review aims to find out the present trend and predicting the future prospect of the concept of a molecular genetics approach to uncover the function of bacteria present in refinery wastewater. The review presents literature that identified and characterized bacteria responsible for the degradation of pollutants in petrochemical refining wastewater using culture methods and molecular methods, such as the genomic, metabolomic and proteomic approach. The research hereby recommends the need for further research on a molecular approach to uncover the function of bacteria in petrochemical refinery wastewater using metaproteomic and metabolomic approach.
\end{abstract}

Keywords: biostimulation, bioremediation, metabolites, metaproteomic, metagenomic, adsorption

\section{Introduction}

Water is the most important asset in the universe. This is based on the fact that all life procedures require the utilization of water (Long et al., 2019; Longyang, 2019). The ever expanding world population and adoption of industrial lifestyle have inevitably lead to an increase in water shortage and water-borne diseases (Jimena Zambrano et al., 2018). Petrochemical refineries produce enormous amounts of wastewater consisting of both organic and inorganic pollutants, due to its refining process which involves cracking, resulting in the formation of simpler organic substances including benzene, toluene, biphenyl, cresol, cumene, ethylbenzene, hexane and methyl-butyl, etc. (Serio et al., 2018). The wastewater created contains oxygen depleting organisms and can lead to the production of toxic compounds e.g. heavy metals, phenol, oil and grease, bicarbonate etc. which, if not properly treated, could be discharged into the environment (Jimena Zambrano et al., 2018). These pollutants are created in an effort to increase the standard of living for man, but ironically the unplanned intrusion of these pollutants can reverse the same standard and affect the environment in a negatively way (Zhao et al., 
2018). These pollutants have the capacity to pollute underground water, or where it is released without proper treatment it affects Biochemical Oxygen Demand (BOD) and Chemical Oxygen Demand (COD) of surface water.

Refinery wastewater contains microbial world which has the ability to withstand the pollutants of petrochemical wastewater (Gunawardena et al., 2018; Karbassi et al., 2018; Liu et al., 2018). Bioremediation is rising in importance owing to the way that the technique is has been efficiently used for remediation of the polluted site over other biological and conventional methods (Pettit et al., 2018; Ribeiro et al., 2018; Singh et al., 2018; Zhang et al., 2018). There is an increasing trend in the quantification of a molecular cellular component such as Deoxyribonucleic acid (DNA), Ribonucleic acid (RNA), Protein and metabolites of an organism (Vendramel et al., 2015; Asl et al., 2018; Dalman et al., 2018). The use of DNA and RNA sequence has been dominantly used. However, proteins and metabolites are functional entities in cell and therefore could be used to give an accurate insight into how Bacteria respond to pollutants in refinery wastewater (Rafat et al., 2018; Al-Namnam et al., 2019; Megarajan et al., 2019). This review is aimed at knowing the present trend and predicting the future prospect of the concept of a molecular genetics approach to uncover the function of bacteria present in refinery wastewater.

\section{Petrochemical refinery pollutants}

The water consumption rate of petrochemical refining industries is worrisome owing to the fact that large volumes of water are used in the refining of petroleum thus leading to the creation of wastewater (Licht and Isebrands, 2005). Factors such as crude oil composition and extraction mechanisms play a great role in the determination of the properties of wastewater resulting from crude oil refining attributing to the reason why was petrochemical refining wastewater varies from one refinery to the other (Colborne et al., 2019). Research worldwide has shown that refinery wastewater contains diverse pollutants that are either organic or inorganic (Donner et al., 2019). Organic pollutants can be subdivided into aliphatic or aromatic pollutants (Ghazouani et al., 2019). These pollutants influence the production of the aquatic environment by facilitating the process of oxygen depletion which leads to increased chemical oxygen demand (COD) and biological oxygen demand (BOD) (Mkhinini et al., 2019; Sancho et al., 2019; Sousa et al., 2019; Williams et al., 2019). Many studies have associated carcinogenic and mutagenic effect caused to microorganisms, macro-organism, and even human beings to be due to exposure to organic pollutants particularly BTEX benzene (toluene, ethylbenzene, and xylene) (Colborne et al., 2019), PAH (polycyclic aromatic hydrocarbon) (Chen et al., 2019), MTBE (methyl tert-butyl ether) (Krizman-Matasic et al., 2019; Nie et al., 2019; Zhang et al., 2019). Some organic pollutants that are likely found in petrochemical refining wastewater and the possible environmental effects associated with them are summarized in Table 1.

Inorganic pollutants in petrochemical refinery wastewater range from heavy metals to phosphorus. Heavy metals are one of the major problems associated with petrochemical refining wastewater owing to their non-biodegradable ability (Chen et al., 2019; Derakhshan et al., 2019). Though most times these metals are in minute concentration measured in microgram, they tend to accumulate till they get to toxic level. Research has demonstrated that heavy metals are harmful in both elemental and soluble form. The most reported toxic metals include $\mathrm{Cd}, \mathrm{Pb}, \mathrm{Hg}, \mathrm{Ag}, \mathrm{Cr}$ and $\mathrm{As}$ 
(Derakhshan et al., 2019). Heavy metals such as $\mathrm{Cr}, \mathrm{Cd}$, and $\mathrm{Pb}$ are highly toxic to plants because they are needed by plants in either minute quantity or not needed, whereas heavy metals such as $\mathrm{Cu}$ and $\mathrm{Zn}$ are used by plants but can be highly toxic to plants also at higher concentration (Ioannou-Ttofa et al., 2019). Iron which is a vital mineral needed by the body becomes toxic at a higher concentration of above $1.6 \mathrm{mg} / \mathrm{l}$ leading to hemorrhagic and sloughing of the stomach particularly the mucosa area. Some heavy metals needed for plants growth are carcinogenic to human e.g. Ni (Kolecka et al., 2019). Another pollutant present in petrochemical refining wastewater is a nitrogen compound which is sometimes in combine state with hydrogen forming ammonia (Long et al., 2019). Phosphorus is also another pollutant present in petrochemical refining wastewater (Tahtouh et al., 2019). The worrisome situation associated with the presences of phosphorus and nitrogen compound in petrochemical refinery wastewater is the fact that both contribute immensely to eutrophication, a process that encourages the growth of algae leading to a scenario refers to as algae blooms. Algae blooms tend to deplete oxygen and some of the algae are directly poisonous to fishes and other aquatic organisms. The situation thereby leads to a drastic reduction in aquatic productivity (Costa et al., 2019; Tahtouh et al., 2019; Tang et al., 2019). It is thereby of paramount importance to remove Nitrogen and phosphorus from petrochemical refining wastewater (Costa et al., 2019).

Table 1. Organic pollutants and environmental impacts

\begin{tabular}{|c|c|c|c|}
\hline $\mathbf{S} / \mathbf{N}$ & Pollutant & Environmental impact & References \\
\hline 1 & Benzene & $\begin{array}{l}\text { It hinders the growth of plants and other } \\
\text { terrestrial animals and could lead to their death } \\
\text { through extended exposure. The presence in the } \\
\text { aquatic environment leads to behavioral } \\
\text { changes, health instability of the organisms and } \\
\text { low reproductive rate }\end{array}$ & $\begin{array}{l}\text { Cuo et al. (2018), } \\
\text { Staehelin et al. } \\
\quad(2018)\end{array}$ \\
\hline 2 & Toluene & $\begin{array}{l}\text { Causes mutagenic and carcinogenic effects to } \\
\text { micro organisms and other macro organisms }\end{array}$ & $\begin{array}{l}\text { Lagoviyer et al. } \\
\text { (2018) }\end{array}$ \\
\hline 3 & Biphenyl & \begin{tabular}{|c|} 
In humans, exposure to biphenyl leads to eye \\
and skin irritation, toxic effect on liver, kidney \\
and nervous system. In the aquatic environment, \\
exposure to biphenyl leads to behavioral \\
changes and low reproductive rate
\end{tabular} & $\begin{array}{l}\text { Lauren Hayashi } \\
\text { (2014), Li Z } \\
\text { (2016) }\end{array}$ \\
\hline 4 & Cresol & $\begin{array}{c}\text { Exposure can lead to severe gastrointestinal } \\
\text { damage which could eventually lead to the } \\
\text { death of an organism }\end{array}$ & Shi et al. (2019) \\
\hline 5 & Cumene & $\begin{array}{c}\text { No observable effect has been recorded in a } \\
\text { mammal and some larger vertebrates but } \\
\text { exposure to cumene inhibits photosynthetic } \\
\text { activities in some algae and also shows positive } \\
\text { effects on some invertebrates }\end{array}$ & $\begin{array}{l}\text { Junqueira et al. } \\
\qquad(2018)\end{array}$ \\
\hline 6 & Ethylbenzene & $\begin{array}{c}\text { Long time exposure causes the damage of the } \\
\text { kidney can lead to an irreversible damage to the } \\
\text { inner ear }\end{array}$ & $\begin{array}{l}\text { El-Hashemy and } \\
\text { Ali (2018) }\end{array}$ \\
\hline 7 & Hexane & \begin{tabular}{|c|}
$\begin{array}{c}\text { Exposure causes body weight lost, neurological, } \\
\text { reproductive and developmental defects in } \\
\text { exposed organisms }\end{array}$ \\
\end{tabular} & $\begin{array}{l}\text { El-Hashemy and } \\
\text { Ali (2018) }\end{array}$ \\
\hline
\end{tabular}




\begin{tabular}{c|c|c|c}
\hline 8 & Methyl-butyl ether & $\begin{array}{c}\text { Causes leukemia and lymphoma (blood cancer), } \\
\text { cancer of the kidney and nerve dysfunction. In } \\
\text { an aquatic environment, it rapidly leads to the } \\
\text { depletion of dissolved oxygen }\end{array}$ & $\begin{array}{c}\text { El-Hashemy and } \\
\text { Ali (2018) }\end{array}$ \\
\hline 9 & Xylene & $\begin{array}{c}\text { Causes the dysfunctions of the liver, kidney and } \\
\text { nervous system. A lot of neurological effects } \\
\text { have also been reported }\end{array}$ & $\begin{array}{c}\text { El-Hashemy and } \\
\text { Ali (018) }\end{array}$ \\
\hline 10 & Phenol & $\begin{array}{c}\text { Causes muscles tremor resulting into walking } \\
\text { difficulty and gastrointestinal damage and even } \\
\text { death }\end{array}$ & $\begin{array}{c}\text { Wang et al. } \\
\text { (2018) }\end{array}$ \\
\hline 12 & Nepthalene & $\begin{array}{c}\text { Exposure could lead to impaired learning and } \\
\text { reproductive defects particularly damage in } \\
\text { sperm. Possible carcinogenic effects have been } \\
\text { reported to result as a result of exposure to } \\
\text { styrene }\end{array}$ & $\begin{array}{c}\text { Arabjafari et al. } \\
\text { (2017) }\end{array}$ \\
\hline 13 & $1,2,3$ Trimethylbenzene & $\begin{array}{c}\text { Causes mutagenic and carcinogenic effects to } \\
\text { micro organisms and other macro organisms } \\
\text { and also associated with damage of red blood } \\
\text { cells }\end{array}$ & $\begin{array}{c}\text { Wang et al. } \\
\text { (2018) }\end{array}$ \\
\hline & $\begin{array}{c}\text { No normal background level adverse effect to } \\
\text { human have been reported but on a high } \\
\text { exposure lead to Vomiting, tension, wheezing } \\
\text { and may be injurious to the blood }\end{array}$ & $\begin{array}{c}\text { Kostrzewski et } \\
\text { al. (1997) }\end{array}$ \\
\hline
\end{tabular}

\section{Remediation of petrochemical refining wastewater by bacteria}

The use of Bacteria for bioremediation can be dated to 1972 when soil pollution resulting from the bursting of Ambler pipeline was bioremediation (Raymond, 1976). Bioremediation technology in the remediation of petroleum wastewater holds a promising start owing to the fact that its earliest research has shown high pollutants removal efficiency compared to other biological and conventional methods (Bako et al., 2008; Peng et al., 2017; Panasia and Philipp, 2018).

Bioremediation of organic pollutants in refinery wastewater can occur naturally by the degradation of the pollutants to a minimum concentration to exert toxicity except for persistence organic compound such as polycyclic aromatic hydrocarbon (PAHs) and benzene, toluene, ethylbenzene and xylene (BTEX) (Horemans et al., 2017; Buryska et al., 2018; Nikolaivits et al., 2018). Although, the rate at which organic pollutants degrade naturally is very slow hence the reason why bacteria are used to engineer the process (Wang et al., 2017).

Petrochemical refining wastewater treatment using bioremediation techniques is less energy, pressure, and temperature consuming if compare with another convectional method (Silva et al., 2012; Ojha et al., 2013; Banerjee and Ghoshal, 2016). Bioremediation potential of bacteria to degrade refinery wastewater depend on its metabolic activities (Eberlein et al., 2013; Boll et al., 2014; Nikel et al., 2016) which involves the ability of the bacteria to introduce molecular oxygen into the wastewater to catabolize the hydrocarbon present in the wastewater utilizing it as a source of energy and carbon (Moghadam et al., 2016; Banerjee and Ghoshal, 2017; Iqbal et al., 2018). Thapa et al. (2012) stated that the bacteria with the potentiality to degrade petroleum pollutants includes Pseudomonas sp, Beijerinckia sp, Chlorobacteria sp, Antinetobacter sp, Nocardia sp, Lavobacteria sp, Streptomyces sp, Cyanobacteria sp, Baccilus sp, 
Moraxella sp, Corynecbacteria sp, Aeromonas sp, Mycobactena sp etc. Although, in the treatment of petrochemical refining wastewater these bacteria must not be indigenous bacteria inhabiting the wastewater because nonindigenous bacteria isolated from other sources can be used to treat this wastewater (Chaudhary and Borah, 2011; Singh et al., 2013; Rodriguez-Mateus et al., 2016). Remediation of petrochemical refining wastewater using bacteria is associated with little or no adverse effect to the ecosystem on like in the case of phytoremediation where the disposal of the plants use for remediation becomes another problem to the ecosystem (Boroujeni et al., 2014; Bahobail et al.,, 2016; Duniya, 2016). Many researchers have used indigenous and nonindigenous bacteria in the treatment of refinery petrochemical wastewater as summarized in Table 2.

Table 2. Literature on bacterial consortia effectively used for bioremediation

\begin{tabular}{|c|c|c|c|}
\hline SN & Bacterial consortia & Pollutant removed & Reference \\
\hline 1 & $\begin{array}{c}\text { Aeromonas punctata } \\
\text { Aeromonas caviae } \\
\text { Stenotrophomonas maltophilia } \\
\text { Ochrobactrum intermedium } \\
\text { Rhodococcus sp }\end{array}$ & $\begin{array}{l}\text { Crude oil } \\
\text { Chemical Oxygen Demand (COD) } \\
\text { Biological Oxygen Demand (BOD) } \\
\text { Total petroleum hydrocarbion (TPH) }\end{array}$ & $\begin{array}{l}\text { Gargouri et } \\
\text { al. (2011) }\end{array}$ \\
\hline 2 & Bacillus cereus & COD and BOD & $\begin{array}{c}\text { Banerjee and } \\
\text { Ghoshal } \\
(2016)\end{array}$ \\
\hline 3 & $\begin{array}{c}\text { Alcaligenes odorans } \\
\text { Bacillus subtilis } \\
\text { Corybacterium propinquum } \\
\text { Pseudomonas aeroginosa }\end{array}$ & Crude oil and phenol & $\begin{array}{l}\text { Singh et al. } \\
\quad(2013)\end{array}$ \\
\hline 4 & $\begin{array}{c}\text { Alcanivorax borkumensis } \\
\text { Alcanivorax dieselolei } \\
\text { Anderseniella baltica } \\
\text { Devosia albogilva } \\
\text { Gordonia alkalivorans } \\
\text { Gordonia amicalis } \\
\text { Gordonia paraffinivorans } \\
\text { Haloferax volcanii } \\
\text { Marinobacter gudaonensis } \\
\text { Methylopila capsulata } \\
\text { Mycobacterium aromaticivorans } \\
\text { Mycobacterium aubagnense } \\
\text { Mycobacterium chelonae } \\
\text { Mycobacterium doricum } \\
\text { Mycobacterium llatzerense } \\
\text { Mycobacterium monacense } \\
\text { Mycobacterium rutilum } \\
\text { Petrimonas sulfuriphila } \\
\text { Proteiniphilum acetatigenes } \\
\text { Saccharospirillum impatiens } \\
\text { Williamsia marianensis } \\
\text { Williamsia muralis }\end{array}$ & $\begin{array}{c}\text { Total petroleum hydrocarbion } \\
\text { Electrical Conductivity (EC) } \\
\text { Total Solid } \\
\text { Volatile Solid } \\
\text { Total Nitrogen } \\
\text { Total Kheldhal Nitrogen }\end{array}$ & $\begin{array}{l}\text { Gargouri et } \\
\text { al. (2014) }\end{array}$ \\
\hline 5 & $\begin{array}{c}\text { Rhodococcus pyridinivorous } \\
\text { Advenella faeciporci } \\
\text { Pseudomonas aeroginosa }\end{array}$ & Phenol & $\begin{array}{c}\text { Moghadam et } \\
\text { al. (2016) }\end{array}$ \\
\hline
\end{tabular}




\begin{tabular}{|c|c|c|c|}
\hline 6 & $\begin{array}{l}\text { Pseudomonas } s p \\
\text { Acinetobacter } s p \\
\text { Kelibsiella } s p \\
\text { Citrobacter } s p \\
\text { Shigella } s p \\
\end{array}$ & Phenol & $\begin{array}{l}\text { Ojha et al. } \\
\text { (2013) }\end{array}$ \\
\hline 7 & $\begin{array}{l}\text { Diaphorobacter } s p \\
\text { Pseudomonas } s p \\
\text { Thauera sp } \\
\text { Comamonas } s p \\
\end{array}$ & $\begin{array}{l}\text { Biphenyl } \\
\text { Naphthalene } \\
\text { Benzoate }\end{array}$ & $\begin{array}{l}\text { Silva et al. } \\
\quad(2012)\end{array}$ \\
\hline 8 & $\begin{array}{l}\text { Diaphorobacter } s p \\
\text { Paracoccus } s p\end{array}$ & Polycyclic aromatic hydrocarbons (PAHs) & $\begin{array}{c}\text { Sanches et al. } \\
(2017)\end{array}$ \\
\hline 9 & $\begin{array}{c}\text { Bacillus subtilis } \\
\text { Micrococcus luteus } \\
\text { Pseudomonas aeroginosa }\end{array}$ & Oil and grease, COD and BOD & Musa (2015) \\
\hline 10 & $\begin{array}{c}\text { Pseudomonas aeroginosa } \\
\text { Penicillium janthinellum }\end{array}$ & Crude oil & $\begin{array}{c}\text { Bako et al. } \\
(2008)\end{array}$ \\
\hline 11 & $\begin{array}{l}\text { Achromobacter } s p \\
\text { Pseudomonas } s p \\
\text { Alcaligenes } s p \\
\end{array}$ & $\begin{array}{l}\text { Phenol } \\
\text { Benzene }\end{array}$ & $\begin{array}{l}\text { Iqbal et al. } \\
\quad(2018)\end{array}$ \\
\hline 12 & $\begin{array}{l}\text { Bacillus licheniformis } \\
\text { Bacillus shaericus } \\
\text { Bacillus brevis }\end{array}$ & Total petroleum hydrocarbon & $\begin{array}{l}\text { El-Borai et } \\
\text { al. }(2016)\end{array}$ \\
\hline 13 & $\begin{array}{c}\text { Rastonia picketti } \\
\text { Alcaligenes piechaudi } \\
\text { Bacillus subtilis } \\
\end{array}$ & Total petroleum hydrocarbon & \\
\hline 14 & $\begin{array}{l}\text { Burkholderia cepacia } \\
\text { Cornebacterium sp }\end{array}$ & $\begin{array}{c}\text { COD } \\
\text { BOD } \\
\text { Phenol } \\
\text { Total petroleum hydrocarbon } \\
\text { Oil and grease } \\
\end{array}$ & $\begin{array}{l}\text { Ajao et al. } \\
\quad(2013)\end{array}$ \\
\hline 12 & Serratia marcescens & $\begin{array}{l}\text { Trichloroethylene } \\
\text { Tetrachloroethylene } \\
\text { Polyvinylchloride }\end{array}$ & $\begin{array}{l}\text { Li et al. } \\
(2008)\end{array}$ \\
\hline 13 & $\begin{array}{l}\text { Pseudomonas aeruginosa } \\
\text { Bacillus thermosaudia }\end{array}$ & $\begin{array}{l}\text { PAHs (Benzo-pyrene, benzo }(\mathrm{k}) \\
\text { fluoranthene, naphthalene, phenanthrene, } \\
\text { fluorine, and anthracene) }\end{array}$ & $\begin{array}{l}\text { Pugazhendi } \\
\text { et al. (2017) }\end{array}$ \\
\hline 14 & Pseudomonia putida & $\begin{array}{l}\text { Hexadecane } \\
\text { Anthracene } \\
\text { Naphthalene }\end{array}$ & $\begin{array}{l}\text { Yalcin et al. } \\
\qquad(2011)\end{array}$ \\
\hline 12 & $\begin{array}{c}\text { Alcanivorax, } \\
\text { Marinobacter, } \\
\text { Alphaproteobacteria } \\
\text { Pseudomonas }\end{array}$ & Oil & $\begin{array}{l}\text { Kostka et al. } \\
\quad(2011)\end{array}$ \\
\hline 13 & $\begin{array}{l}\text { Pseudomonas stutzeri, } \\
\text { Rhodococcus erythropolis } \\
\text { Alcanivorax borkumensis, }\end{array}$ & Crude oil & $\begin{array}{l}\text { Santisi et al. } \\
\text { (2015) }\end{array}$ \\
\hline
\end{tabular}

It will be noticed from the Table 2 that despite the fact that benzene, toluene, biphenyl, cresol, cumene, ethylbenzene, hexane, and methyl-butyl ether are very poisonous pollutants present in petrochemical refining wastewater, there is still scanty literature with respect to the bioremediation of these pollutants in refining wastewater 
using bacteria. Instead, a significant number of researches on bioremediation of petrochemical wastewater centered the research on total petroleum hydrocarbon which encompasses all. Quite a number of researches have shown the potentiality of some bacteria to bioremediate total petroleum hydrocarbon in petrochemical refining wastewater but it is of paramount importance to be case specific with respect to the potentiality of bacteria that can bioremediate benzene, toluene, biphenyl, cresol, cumene, ethylbenzene, hexane and methyl-butyl ether in the free state because these pollutants varied in state and testing site and so also do their ecological effects. Table 2 also shows that scanty literature exists for the bioremediation of heavy metals from petrochemical refining wastewater. The poor literature in the bioremediation of heavy metals from petrochemical refining wastewater could be attributed to the nonbiodegradable behavior of heavy metals. Although the literature has shown the potentiality of bacteria to remove heavy metal from a polluted site by biosorption and enzymatic degradation, the process of biosorption is illustrated by Figure 2. The poor literature in the bioremediation of phosphorus and nitrogenous compound in petrochemical, refinery wastewater is also worrisome because degradation catalyst by bacteria is dependable on environmental conditions.

\section{Biodegradation of pollutants in petrochemical refining wastewater}

Petrochemical and refining wastewater contains pollutants that are either organic or inorganic as shown in Table 2. The degradation of organic pollutants depends on the aerobic and anaerobic pathway as shown in Figure 1 while in the case of inorganic pollutants it occurs by adsorption, absorption or the action of enzyme release by the bacteria as shown in Figure 1 (Fuchs et al., 2011).

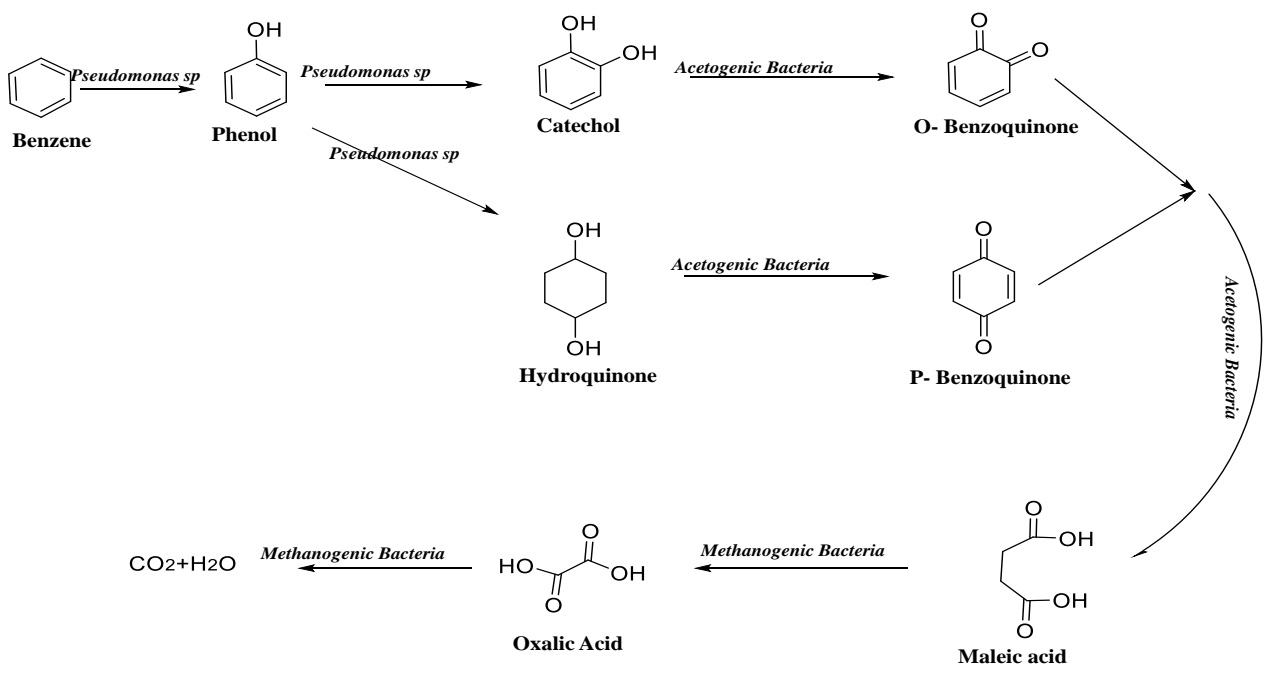

Figure 1. Proposed process of biodegradation of benzene by bacteria

Bacteria possess high potentiality in the biodegradation of hazardous petrochemical wastewater as shown in Figure 1. To further enhance the Biodegradation by bacteria particularly in a contaminated site, there is the need to study the condition in which bacteria best perform it functions and the enzymes involved in this process. The role of enzymes in the degradation of petrochemical pollutants particularly organic compounds 
was reported by Scoma et al. (2017) to be due to Rieske non-heme iron oxygenases, flavoprotein, Monooxgenases or soluble di iron monooxygenases.

Heavy metal present in petrochemical wastewater is nonbiodegradable due to their persistence nature as such this persistence pollutants are removed from petrochemical wastewater by adsorption as shown in Figure 2. Researchers such as Gutnick and Bach (2000), Feng et al. (2012) and Oves et al. (2013) have used the dead and live culture of bacteria for heavy metal removal by adsorption. The efficiency of heavy metal adsorption by bacteria depends on the speciation, behavior, transportation mechanism and the fate of heavy metal in binding with the functional group of the bacteria as shown in Figure 2. To understand the mechanism involved in adsorption of heavy metals by bacteria, studies on cell surface characterization, functional group identification, acidic and basic active site identification etc have been performed by researchers such as Vecchio et al. (1998), Banerjee et al. (2018).

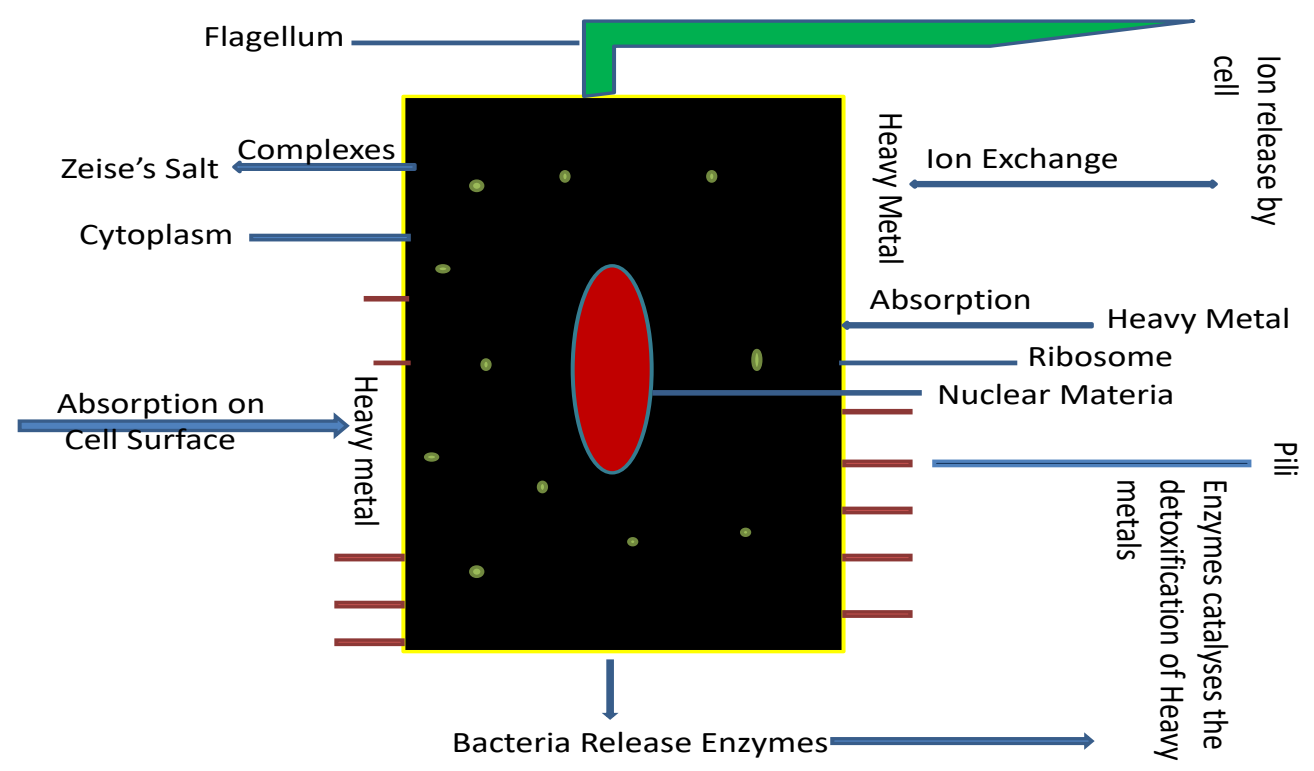

Figure 2. Process of heavy metal removal by bacteria (Jin et al., 2018)

\section{Petrochemical refining wastewater remediation strategies and principles}

The strategies used in the bioremediation of petrochemical refining wastewater include biostimulation, bioaugmentation, bioattenuation and the use of genetically modified bacteria.

\section{Biostimulation}

This is a strategy that involves the use of indigenous bacteria for the treatment of petrochemical refining wastewater. The indigenous bacteria used for biostimulation are supported by nutrients which maybe inform of cations or anions to enhance the biodegrading capability of the bacteria (Jemli et al., 2017). The addition of nutrient supports the metabolic process of the bacteria thereby facilitating the degradation of pollutants present in refinery wastewater. Sarkar et al. (2016) reported high total petroleum hydrocarbon degradation of about $80 \%$ after the retention time of 90 days after bio stimulating indigenous bacteria by enhancing the nitrate constituent of the wastewater (Lin et al., 2012). 


\section{Bioaugmentation}

This is a strategy employ in the treatment of petrochemical wastewater in which foreign bacteria is introduced into petrochemical refining wastewater to enhance the biodegradation ability of the indigenous bacteria (Yan et al., 2014). To have a successful bioaugmentation of petrochemical refining wastewater, the adaptability of the foreign bacteria must be considered owing to competition that may exist between indigenous and foreign bacteria, another problem that the foreign bacteria may face include predation by protozoa. Dueholm et al. (2014) recorded high removal efficiency of methyl ethyl ketone remediation using bioaugmentation assisted bioremediation using Rhodococcus pyridinivorans. Yan et al. (2013) also recorded high cresol removal efficiency using Pseudomonas sp supported by bioaugmentation.

\section{Bioattenuation}

Bioattenuation is a type of strategy which employs natural biodegradation mechanism of bacteria to treat petrochemical wastewater (Huling et al., 2002). The presence of other refinery wastewater pollutants such as phosphate, sulfate, nitrate etc stimulates the process of bioattenuation leading to the degradation of BTEX and PAHs as shown in Figure 1. Bioattenuation is the process that occurs when wastewater is stored in stabilization pond. The bioattenuation process is achieved either aerobically or anaerobically by acetogenic bacteria and methanogenic bacteria (Nijenhuis et al., 2004).

\section{The use of genetically modified bacteria}

Genetic modification of bacteria genome was among the earliest contribution in the field of genetic engineering owing to their simple structures. The use of the genetically modified bacteria in the degradation of hydrocarbons and chlorinated hydrocarbon is a cost-effective an emerging trend in bioremediation. The degradation pathway of organic compounds as shown in Figure 1 have been reported by researchers such as Scoma et al. (2017). Also Duarte et al. (2014) reported that enzymes such as dioxygenase, flavoprotein monooxygenase, catechol 2-3 dioxygenases, protocatechuate, gentisate dioxygenase etc are responsible for the degradation organic compound as shown in Figure 1. The used of genetically modified bacteria in degradation of petrochemical wastewater is beyond just the use of the natural biodegrading potential of bacteria. genes are introduced into bacteria by recombinant DNA technology to enhances the bioremediation of both organic and inorganic Pollutant.

\section{Molecular characterization of bacteria present in petrochemical refinery wastewater}

Molecular characterization of bacteria present in petrochemical refinery wastewater involves the investigation of the chemical functional groups or constituent in bacteria cell that allow the bacteria to be able to survive in petrochemical refinery wastewater and even bring about the bioremediation by degradation of both organic and inorganic pollutants presents in the wastewater (Chaudhary and Borah, 2011; Singh et al., 2013). The technique used in the molecular characterization of bacteria present in petrochemical refinery wastewater includes the following approaches: 
- Genomic approach

- Proteomic approach

- Metabolomic approach (Bahobail et al., 2016; Duniya, 2016; RodriguezMateus et al., 2016)

The methods stated above are changing the understanding of bacteria functions in petrochemical refinery wastewater from a simple study of the sequences of gene, protein or metabolites to a more complex and detailed approach showing the role of bacterial in petrochemical wastewater environment (Hobert, 2010). The molecular approach to petrochemical wastewater bacteria characterization is achieved at the microbial community rather than a single bacteria species due to the fact that biodegradation activities of bacteria depend on consortia (Santisi et al., 2015).

\section{Genomic approach in the uncovering of bacteria function in petrochemical refining wastewater}

Bacteria genome simply refers to as the total sets of DNA found in bacteria. Genomic investigation of bacteria genome is centered towards the study of the bacteria genomic structure, bacteria genomic evolution, bacteria genomic mapping, and editing of a bacterial genome (Gilbert and Scott, 2017).

This technique has been helpful in the determination of how bacteria cell is able to successfully leave in petrochemical refinery wastewater and the function they play in this wastewater. This has also helped in the determination of the most efficient bacteria to be used in the remediation of petrochemical wastewater (Larsen et al., 2012).

The aspect of genomic, that is the concern with the study of environmental samples such as petrochemical refining wastewater, is referred to as metagenomic or ecogenomic. This technique employs the use of 16S rRNA gene (16S rDNA) sequences analysis method for the identification of bacteria strain. These methods have shown a better advantage over the culture method of the function of bacteria in petrochemical refinery wastewater. The major sequential method employed includes extraction of DNA, PCR amplification of the 16S rRNA gene, nucleotide sequence determination (sequencing) and sequences comparison with available data (Fuks et al., 2018). The sequencing and analysis of bacteria genome by the use of DNA sequencing, RNA sequencing, and bioinformatics techniques have been utilized in the assembling and analysis of the function and structure of the entire organism genome of bacteria presents in petrochemical refinery wastewater (Toshchakov et al., 2017).

\section{Metabolomic approach in the uncovering of bacteria function in petrochemical refining wastewater}

The metabolomic approach of studying the function of a living organism in an environment is highly complex because it tends to give more detail or complex cellular pathways and biological mechanisms in organisms (Vinaixa et al., 2016; Beale et al., 2018a; Beale et al., 2018b). This approach employs the use of small bacteria metabolites including metabolic intermediates hormones, signaling molecules and secondary metabolites to uncover the function play by bacteria (Bonifay et al., 2017).

This approach is used as a basic tool used in functional genomics studies to ascertain the function of the gene (Tang, 2011). This approach holds a promising future towards the ascertaining the function play by bacteria in petrochemical wastewater owing to the 
fact that they are involved in normal growth and development of bacteria as such could provide important detail to why the organism was able to survive and develop fully in the presence of petrochemical wastewater pollutants (Foght, 2008). Metabolites are also involved in activities carried out by antibodies and pigments which is also an important tool for the determination of the reaction pathway in the degradation of organic and inorganic pollutants in petrochemical refining wastewater and biosorption of heavy metals by the bacterial cell (Tang, 2011).

Table 2 summarized some recent contribution done by researchers in the uncovering the function of bacteria in the degradation of petrochemical wastewater making references to metabolomics.

\section{Proteomics approach in the uncovering of bacteria function in petrochemical refining wastewater}

This approach involves the use of proteins to uncover the function of bacteria in petrochemical wastewater. The use of this technique has made possible to know the function of bacterial consortia. The proteomic study that a deal with the study of protein for the particular environmental function is refers to as metaproteomic. The use of metaproteomics approach in the characterization of bacterial consortia has given a better insight to which bacteria consortia is best to be used in the wastewater treatment.

\section{Recent findings on molecular identification and characterization of refinery wastewater}

Genomic DNA extraction from bacteria isolate was performed by Chaudhary and Borah (2011) who shows that Bacillus and Pseudomonas species have the maximum capacity to degrade oil but gave upper hand advantage to Bacillus species. Singh (2013) shows the presence of Alcaligens odorans, Bacillus subtilis, Corynebacterium propinquum and Pseudomonas aeruginosa in petrochemical refinery wastewater. The researcher positively collated high pollutant reduction efficiency to lipolytic activities of the bacteria. Rodriguez-Mateus et al. (2016) using wizard genomic DNA purification Kit (Promega, USA) identified bacterial isolates using amplification and sequencing. Rodriguez-Mateus et al. (2016) detected the present of 10 species of bacterial isolate stating that the bacteria isolates belong to the genus Candida and Bacillus. RodriguezMateus et al. (2016) also show that the bacterial isolates show visible lipolytic activity evidenced by the reduction of in the pollutants of the palm oil refining wastewater. Iqbal et al. (2018) performed molecular characterization by $16 \mathrm{~S}$ rRNA gene sequencing and find out that phenol was degraded completely by Achromobacter species, Pseudomonas specie, and Alcaligenes species. The researcher also reported the significant degradation of benzene by Bacillus species, Enterobacter sp, and Acinetobacter sp. This study is supported by the previous work performed by Bahobail et al. (2016) who shows that Pantoea agglomerans, Acinetobacter iwoffi and Bacillus thuringiensis where fully characterized to be lipolytic to hydrocarbons. Duniya (2016) shows the presences of the gene for hydrocarbon enzymes catechol 2,3 dioxygenase in Enterobacter hormaechei, Escherichia coli, and Shigella flexneni. Boroujeni et al. (2014) reported that the sequences of the gene bank and the highest homology were identified for bacteria belonging to the Nitratireductor aquamarinus and Pseudomonas stutzeri were identified. Igwaran et al. (2018) shows the molecular characterization and antimicrobial resistance pattern by 31 genes of Escherichia coli. Chikkanna et al. (2018) using 
polyphasic taxonomy approach identify bacterial strain including Halomonas Mauramaura, Halomonas nitoreduceus, Halomonas ventose, Halomonas trenophila and Halomonas methanobrevibacter. Azadi et al. (2017) screen and characterized Mycobacteria from the diverse range of Iranian aquatic and terrestrial ecosystem with a harsh and unfavorable environmental condition that can be used in biodegradation of refinery product. The presences of Mycobacterium fortuitum, Mycobacterium flavescens, Mycobacterium paragordonae, Mycobacterium monacense, Mycobacterium fredriksbergense, Mycobacterium aurum, Mycobacterium conceptionense, Mycobacterium porcinum, Mycobacterium aurum, Mycobacterium celeriflavum, Mycobacterium novocastrense, Mycobacterium obuense and 12 isolates belonging to an unknown potentially novel bacterium species. Obi et al. (2016) performed molecular characterization using rRNA gene to indicate the presence of bacteria belonging the genera Stenotrophmonas, Bordetella, Pseudomonas, Brucella, Bacillus, Achromobacter, Ochrobactrum, Advenella, Mycobacterium, Mesorhizobium, Klebsiella, Pusillimonas and Raultella $s p$ with potential to degrade polycyclic aromatic hydrocarbons (PAHs) from oil sludges. Abo-State et al. (2018) was able to isolate Naphthalene tolerance bacteria belonging to Bordetta avium including MAM-P14, MAM-P22, MAM-P25, $M A M-P 26, M A M-P 9$. Nascimento et al. (2018) was able to characterize microbial diversity in sewage sludges from Sao Paulo, Brazil. The presence of high bacterial diversity was noticed with proteobacteria as dominant phylum then Bacteroidetes and Firmicutes, Clostridium were the dominant genus followed by Treponema, Propionibacteria, Syntrophus, and Desulfobulbus. Ma et al. (2015) isolated Strain DN002 from petroleum-contaminated soil which was identified as Achromobacter xylosoxidans. The research shows that during fluoranthene biodegradation, catechol 2, 3 dioxygenases (C23O) activity was augmented 1.5 times more than catechol 1,2 dioxygenase $(\mathrm{C} 12 \mathrm{O})$, which indicated that $\mathrm{C} 23 \mathrm{O}$ played a major role in fluoranthene degradation by DN002. The dominant general was Propionibacterium, Comamonas, Brevundimonas, Methylobactenum, Stenotrophomonas, and Cloacibacterium. Jamal and Pugazhendi (2018) identify the halophilic bacteria trains present in the consortium to include Ochrobacterium halosaudis, Stenotrophomonas maltophilia, Achromobacter xylosoxidans and Mesorhizobium halosaudis. Katyal and Kaur (2018) were able to isolate chromate tolerance bacteria from a treatment plant. The isolates belonging to the Micrococcus luteus include HM 16, HM, 2, HM 3, HM 15. Ibarbalz et al. (2016) used function encoded in metagenome to establish a link between microbial community structure and function in activated sludge. The bacteria detected include Actinobacter, Planctomycetes, Verrucomicrobia, and Chlorobi. Rosso et al. (2016) also use a proteomic approach to investigate the changes of bacteria community overtime, Cyanobacteria, Bacteriodetes, and Proteobacteria were the bacteria that express extracellular hydrolases. Navarro-Locsin and Lim-Jurado (2018) use geno-wide transcriptome and proteome data to confirm most highly expressed organohalide respiration (OHR) rate. He concluded that hydrogenase (HUPL) transcript is the most robust activity biomarker across multiple Dehalcoccoides mecartyi (DMC) strain and in mixed communities including DMC co-culture such as bioaugmentation culture $\left(\mathrm{KB}^{\mathrm{TM}}\right)$. Cernava (2017) used multi-omics approach to characterize functional guilds in an unconventional model system. The community structure of the microbiota was found to be highly similar irrespective of the omics approach. The abundant bacterial orders include Sphingomonadales, Rhodospirillales, Myxococcales, Chthoniobacterales, and Sphingobacteriales. The function played by these Bacterias identified is the 
provision of vitamins and cofactors to the degradation of phenolic compounds like phenylpropanoid, xylenols, and cresols. Matilda and Shanti (2017) isolated trivalent chromium resistant bacterium and identify it by $16 \mathrm{~S}$ rRNA gene sequencing and designated as Alcaligenes faecalis VITSIM2. The organism also showed resistance to copper, cadmium, and certain antibiotics and also shows changes in cell wall content.

Nzila (2018) Isolated and characterized a bacterial strain capable of metabolizing the four fused aromatic ring polycyclic aromatic hydrocarbons (PAH). The analysis of 16S rRNA gene revealed that the bacterium is called Achromobacter xylosoxidans. The proteins involved in the degradation of $\mathrm{PAH}$ are 4-hydroxyphenylpyruvate dioxygenase and homogentisate 1,2-dioxygenase. Otzen et al. (2018) isolated a caprolactamdegrading strain of Pseudomonas jessenii from soil and identified proteins and genes putatively involved in caprolactam metabolism using quantitative mass spectrometrybased proteomics. He demonstrated that caprolactamase consist of two subunits and demonstrated high sequence identity to the 5-oxoprolinases. Escherichia coli cells expressing this caprolactamase did not convert 5-oxoproline but were able to hydrolyze caprolactam to form 6-aminocaproic acid in an ATP-dependent manner. The research concluded that the presence of a caprolactam catabolism gene cluster comprising a set of genes involved in the conversion of caprolactam to adipate.

\section{Conclusion}

Molecular characterizations of bacteria responsible for the bioremediation of petrochemical refining wastewater have a promising future for the control of petrochemical engineered pollution. Bacteria consortia consisting of bacteria which have shown bioremediation capacity for phenol, benzene and other constitutes of petrochemical refining wastewater should be properly utilized as an advantage to properly degrade these pollutants completely from the wastewater before discharge. Molecular characterization will help in the proper identification of the bacteria and enzyme released by the bacteria responsible for the pollutant degradation. The technique will also lead to the identification of the mechanism involved in the ecological adaptation of the bacteria to polluted environment and the role of antibiotic, antimicrobial compound (metabolite and proteins) and bacteria gene in the degradation of petrochemical refining wastewater.

Acknowledgements. The first author appreciate Petroleum Development Fund (PTDF) Nigeria and College of New Energy and Environment, Jilin University for Providing the fund and enabling environment to carry out the research.

\section{REFERENCES}

[1] Abo-State, M. A. M., Riad, B. Y., Bakr, A. A., Aziz, M. F. A. (2018): Biodegradation of naphthalene by Bordetella avium isolated from petroleum refinery wastewater in Egypt and its pathway. - Journal of Radiation Research and Applied Sciences 11: 1-9.

[2] Ajao, A. T., Yakubu, S. E., Umoh, V. J., Ameh, J. B. (2013): Bioremediation of refinery wastewater using immobilised Burkholderia cepacia and Corynebacterium sp and their transconjugants. - Journal of Xenobiotics 3. DOI: https://doi.org/10.4081/xeno.2013.e4. 
[3] Al-Namnam, N. M., Hariri, F., Thong, M. K., Rahman, Z. A. (2019): Crouzon syndrome: genetic and intervention review. - Journal of Oral Biology and Craniofacial Research 9: 37-39.

[4] Arabjafari, M., Fallah, N., Dadvar, M., Nasernejad, B. (2017): Kinetic modeling of styrene biodegradation by Rhodococcus erythropolis PTCC 1767: effect of adaptation to styrene and initial biomass concentration. - Chemical Engineering Communications 204: 182-189.

[5] Asl, N. S., Nejat, F., Mohammadi, P., Nekoukar, A., Hesam, S., Ebrahimi, M., Jadidi, K. (2018): Amniotic membrane extract eye drop promotes limbal stem cell proliferation and corneal epithelium healing. - Cell Journal 20: 459-468.

[6] Azadi, D., Shojaei, H., Mobasherizadeh, S., Naser, A. D. (2017): Screening, isolation and molecular identification of biodegrading mycobacteria from Iranian ecosystems and analysis of their biodegradation activity. - Amb Express 7: 180.

[7] Bahobail, A., Gad El-Rab, S. M. F., Amin, G. A. (2016): Locally isolated bacterial strains with multiple degradation potential capabilities on petroleum hydrocarbon pollutants. Journal of Petroleum \& Environmental Biotechnology 7: 6.

[8] Bako, S. P., Chukwunonso, D., Adamu, A. K. (2008): Bio-remediation of refinery effluents by strains of Pseudomonas aerugenosa and Penicillium janthinellum. - Applied Ecology and Environmental Research 6: 49-60.

[9] Banerjee, A., Ghoshal, A. K. (2016): Biodegradation of real petroleum wastewater by immobilized hyper phenol-tolerant strains of Bacillus cereus in a fluidized bed bioreactor. - 3 Biotech 6(2): 137.

[10] Banerjee, A., Ghoshal, A. K. (2017): Bioremediation of petroleum wastewater by hyperphenol tolerant Bacillus cereus: preliminary studies with laboratory-scale batch process. Bioengineered 8: 446-450.

[11] Banerjee, A., Jhariya, M. K., Yadav, D. K., Raj, A. (2018): Micro-remediation of Metals: A New Frontier in Bioremediation. - In: Hussain, C. M. (ed.) Handbook of Environmental Materials Management. Springer International Publishing, Cham, pp. 136.

[12] Beale, D. J., Crosswell, J., Karpe, A. V., Metcalfe, S. S., Morrison, P. D., Staley, C., Ahmed, W., Sadowsky, M. J., Palombo, E. A., Steven, A. D. L. (2018a) Seasonal metabolic analysis of marine sediments collected from Moreton Bay in South East Queensland, Australia, using a multi-omics-based approach. - Science of the Total Environment 631-632: 1328-1341.

[13] Beale, D. J., Pinu, F. R., Kouremenos, K. A., Poojary, M. M., Narayana, V. K., Boughton, B. A., Kanojia, K., Dayalan, S., Jones, O. A. H., Dias, D. A. (2018b). Review of recent developments in GC-MS approaches to metabolomics-based research. Metabolomics 14: 152.

[14] Boll, M., Loeffler, C., Morris, B. E. L., Kung, J. W. (2014): Anaerobic degradation of homocyclic aromatic compounds via arylcarboxyl-coenzyme A esters: organisms, strategies and key enzymes. - Environmental Microbiology 16: 612-627.

[15] Bonifay, V., Aydin, E., Aktas, D. F., Sunner, J., Suflita, J. M. (2017): Metabolic Profiling and Metabolomic Procedures for Investigating the Biodegradation of Hydrocarbons. - In: McGenity, T. J., Timmis, K. N., Nogales, B. (eds) Hydrocarbon and Lipid Microbiology Protocols: Genetic, Genomic and System Analyses of Communities. Springer, Berlin Heidelberg, Berlin, Heidelberg, pp. 111-161.

[16] Boroujeni, N. A., Hassanshahian, M. H., Khoshrou, S. M. R. (2014): Isolation and characterization of phenol degrading bacteria from Persian Gulf. - International Journal of Advanced Biological and Biomedical Research 22(2): 408-416.

[17] Buryska, T., Babkova, P., Vavra, O., Damborsky, J., Prokop, Z. (2018): A haloalkane dehalogenase from a marine microbial consortium possessing exceptionally broad substrate specificity. - Appl Environ Microbiol 84. DOI: 10.1128/AEM.01684-17. 
[18] Cernava, T. A. E., Aschenbrenner, I. A., Krug, L., Lassek, C., Riede, K., Grube, M., Berg, G. (2017): Deciphering functional diversification within the lichen microbiota by meta-omics. - Microbiome 5: 82. https://doi.org/10.1186/s40168-017-0303-5.

[19] Chaudhary, V. K., Borah, D. (2011): Isolation and molecular characterization of hydrocarbon degrading bacteria from tannery effluent. - International Journal of Plant, Animal and Environmental Sciences 1(2): 36-49.

[20] Chen, H., Zhou, Y., Hu, X., Tian, K., Zhang, J. (2019): Effects of chlortetracycline on biological nutrient removal from wastewater. - Science of the Total Environment 647: 268-274.

[21] Chikkanna, A., Ghosh, D., Kishore, A. (2018): Expression and characterization of a potential exopolysaccharide from a newly isolated halophilic thermotolerant bacteria Halomonas nitroreducens strain WB1. - PeerJ 6: e4684.

[22] Colborne, S. F., Maguire, T. J., Mayer, B., Nightingale, M., Enns, G. E., Fisk, A. T., Drouillard, K. G., Mohamed, M. N., Weisener, C. G., Wellen, C., Mundle, S. O. C. (2019): Water and sediment as sources of phosphate in aquatic ecosystems: The Detroit River and its role in the Laurentian Great Lakes. - Science of the Total Environment 647: 1594-1603.

[23] Costa, J. B., Lima, M. J., Sampaio, M. J., Neves, M. C., Faria, J. L., Morales, S. -Torres, Tavares, A. P. M., Silva, C. G. (2019): Enhanced biocatalytic sustainability of laccase by immobilization on functionalized carbon nanotubes/polysulfone membranes. - Chemical Engineering Journal 355: 974-985.

[24] Cuo, Z., Den, Y., Li, W., Peng, S., Zhao, F., Liu, H., Chen, Y. (2018): Monolithic $\mathrm{Mn} / \mathrm{Ce}$-based catalyst of fibrous ceramic membrane for complete oxidation of benzene. Applied Surface Science 456: 594-601.

[25] Dalman, A., Totonchi, M., Valojerdi, M. R. (2018): Human ovarian theca-derived multipotent stem cells have the potential to differentiate into oocyte-like cells in vitro. Cell Journal 20: 527-536.

[26] Derakhshan, Z., Ehrampoush, M. H., Mahvi, A. H., Dehghani, M., Faramarzian, M., Eslami, H. (2019): A comparative study of hybrid membrane photobioreactor and membrane photobioreactor for simultaneous biological removal of atrazine and CNP from wastewater: A performance analysis and modeling. - Chemical Engineering Journal 355: 428-438.

[27] Donner, M. W., Arshad, M., Ullah, A., Siddique, T. (2019): Unravelled keratin-derived biopolymers as novel biosorbents for the simultaneous removal of multiple trace metals from industrial wastewater. - Science of the Total Environment 647: 1539-1546.

[28] Duarte, M., Jauregui, R., Vilchez, R. -Vargas, Junca, H., Pieper, D. H. (2014): AromaDeg, a novel database for phylogenomics of aerobic bacterial degradation of aromatics. - Database (Oxford) 2014: bau118.

[29] Dueholm, M. S., Albertsen, M., D'Imperio, S., Tale, V. P., Lewis, D., Nielsen, P. H., Nielsen, J. L. (2014): Complete genome of Rhodococcus pyridinivorans SB3094, a methyl-ethyl-ketone-degrading bacterium used for bioaugmentation. - Genome Announcements 2. DOI: 10.1128/genomeA.00525-14.

[30] Duniya, D. A., Maikaje, D., Bawa, Yahaya, U. A., Wuyep, P. A., Abba, D. (2016): Molecular characterization and determination of bioremediation potentials of some bacteria isolated from spent oil contaminated soil mechanic workshops in Kaduna Metropolis. - World Applied Sciences Journal 34(6): 750-759.

[31] Eberlein, C., Johannes, J., Mouttaki, H., Sadeghi, M., Golding, B. T., Boll, M., Meckenstock, R. U. (2013): ATP-dependent/-independent enzymatic ring reductions involved in the anaerobic catabolism of naphthalene. - Environmental Microbiology 15: 1832-1841.

[32] El-Borai, A. M., Eltayeb, K. M., Mostafa, A. R., El-Assar, S. A. (2016): Biodegradation of industrial oil-polluted wastewater in egypt by bacterial consortium immobilized in different types of carriers. - Pol. J. Environ. Stud 25: 1901-1909. 
[33] El-Hashemy, M. A., Ali, H. M. (2018): Characterization of BTEX group of VOCs and inhalation risks in indoor microenvironments at small enterprises. - Science of the Total Environment 645: 974-983.

[34] Feng, M., Chen, X., Li, C., Nurgul, R., Dong, M. (2012): Isolation and identification of an exopolysaccharide-producing lactic acid bacterium strain from chinese paocai and biosorption of $\mathrm{Pb}$ (II) by its exopolysaccharide. - Journal of Food Science 77: T111-T117.

[35] Foght, J. (2008): Anaerobic biodegradation of aromatic hydrocarbons: pathways and prospects. - J Mol Microbiol Biotechnol 15: 93-120.

[36] Fuchs, G., Boll, M., Heider, J. (2011): Microbial degradation of aromatic compounds from one strategy to four. - Nat Rev Microbiol 9: 803-816.

[37] Fuks, G., Elgart, M., Amir, A., Zeisel, A., Turnbaugh, P. J., Soen, Y., Shental, N. (2018): Combining 16S rRNA gene variable regions enables high-resolution microbial community profiling. - Microbiome 6: 17.

[38] Gargouri, B., Karray, F., Mhiri, N., Aloui, F., Sayadi, S. (2011): Application of a continuously stirred tank bioreactor (CSTR) for bioremediation of hydrocarbon-rich industrial wastewater effluents. - Journal of Hazardous Materials 189: 427-434.

[39] Gargouri, B., Karray, F., Mhiri, N., Aloui, F., Sayadi, S. (2014): Bioremediation of petroleum hydrocarbons-contaminated soil by bacterial consortium isolated from an industrial wastewater treatment plant. - Journal of Chemical Technology and Biotechnology 89: 978-987.

[40] Ghazouani, M., Akrout, H., Jellali, S., Bousselmi, L. (2019): Comparative study of electrochemical hybrid systems for the treatment of real wastewaters from agri-food activities. - Science of the Total Environment 647: 1651-1664.

[41] Gilbert, J. A., Scott, N. M. (2017): Introduction to Genetic, Genomic, and System Analyses for Communities. - In: T. J. McGenity, Timmis, K. N., Nogales, B. (eds.) Hydrocarbon and Lipid Microbiology Protocols: Genetic, Genomic and System Analyses of Communities. Springer, Berlin, Heidelberg, pp. 1-4.

[42] Gunawardena, A., White, B., Hailu, A., Wijeratne, E. M. S., Pandit, R. (2018): Policy choice and riverine water quality in developing countries: An integrated hydro-economic modelling approach. - Journal of Environmental Management 227: 44-54.

[43] Gutnick, D. L., Bach, H. (2000): Engineering bacterial biopolymers for the biosorption of heavy metals; new products and novel formulations. - Applied Microbiology and Biotechnology 54: 451-460.

[44] Hobert, O. (2010): The impact of whole genome sequencing on model system genetics: get ready for the ride. - Genetics 184: 317-319.

[45] Horemans, B., Raes, B., Brocatus, H., T'Syen, J., Rombouts, C., Vanhaecke, L., Hofkens, J., Springael, D. (2017): Genetic (In) stability of 2,6Dichlorobenzamide catabolism in aminobacter sp strain MSH1 biofilms under carbon starvation conditions. - Appl Environ Microbiol 83. DOI: 10.1128/AEM.00137-17.

[46] Huling, S. G., Pivetz, B., Stransky, R. (2002): Terminal electron acceptor mass balance: Light nonaqueous phase liquids and natural attenuation. - Journal of Environmental Engineering-Asce 128: 246-252.

[47] Ibarbalz, F. M., Orellana, E., Figuerola, E. L., Erijman, L. (2016): Shotgun metagenomic profiles have a high capacity to discriminate samples of activated sludge according to wastewater type. - Appl Environ Microbiol 82: 5186-5196.

[48] Igwaran, A., Iweriebor, B., Okoh, A. (2018): Molecular characterization and antimicrobial resistance pattern of escherichia coli recovered from wastewater treatment plants in Eastern Cape South Africa. - International Journal of Environmental Research and Public Health 15: 1237.

[49] Ioannou-Ttofa, L., Raj, S., Prakash, H., Fatta, D. -Kassinos. (2019): Solar photo-Fenton oxidation for the removal of ampicillin, total cultivable and resistant E-coli and ecotoxicity from secondary-treated wastewater effluents. - Chemical Engineering Journal 355: 91-102. 
[50] Iqbal, A., Arshad, M., Hashmi, I., Karthikeyan, R., Gentry, T. J., Schwab, A. P. (2018): Biodegradation of phenol and benzene by endophytic bacterial strains isolated from refinery wastewater-fed Cannabis sativa. - Environmental Technology 39: 1705-1714.

[51] Jamal, M. T., Pugazhendi, A. (2018): Degradation of petroleum hydrocarbons and treatment of refinery wastewater under saline condition by a halophilic bacterial consortium enriched from marine environment (Red Sea), Jeddah, Saudi Arabia. - 3 Biotech 8. DOI: 10.1007/s13205-018-1296-x.

[52] Jemli, M., Zaghden, H., Rezgi, F., Kchaou, S., Aloui, F., Sayadi, S. (2017): Biotreatment of petrochemical wastewater: a case study from Northern Tunisia. - Water Environment Research 89: 228-237.

[53] Jimena Zambrano, M., Rautenberg, G. E., Bonifacio, A. F., Filippi, I., Ame, M. V., Bonansea, R. I., Hued, A. C. (2018): Effects of water quality on aspects of reproductive biology of Cnesterodon decemmaculatus. - Science of the Total Environment 645: 10-21.

[54] Jin, Y., Luan, Y., Ning, Y., Wang, L. (2018): Effects and mechanisms of microbial remediation of heavy metals in soil: a critical review. - Applied Sciences-Basel 8.

[55] Junqueira, P. G., Mangili, P. V., Santos, R. O., Santos, L. S., Prata, D. M. (2018): Economic and environmental analysis of the cumene production process using computational simulation. - Chemical Engineering and Processing 130: 309-325.

[56] Karbassi, A. R., Tajziehchi, S., Khoshghalb, H. (2018): Speciation of heavy metals in coastal water of Qeshm Island in the Persian Gulf. - Global Journal of Environmental Science and Management 4: 91-98.

[57] Katyal, P., Kaur, G. (2018): Reduction of Cr (VI) by Micrococcus luteus isolate from common effluent treatment plants (CETPs). - International Journal of Current Microbiology and Applied Sciences 7: 693-710.

[58] Kolecka, K., Gajewska, M., Stepnowski, P., Caban, M. (2019): Spatial distribution of pharmaceuticals in conventional wastewater treatment plant with sludge treatment reed beds technology. - Science of the Total Environment 647: 149-157.

[59] Kostka, J. E., Prakash, O., Overholt, W. A., Green, S. J., Freyer, G., Canion, A., Delgardio, J., Norton, N., Hazen, T. C., Huettel, M. (2011): Hydrocarbon-degrading bacteria and the bacterial community response in gulf of mexico beach sands impacted by the deepwater horizon oil spill. - Appl Environ Microbiol 77: 7962-7974.

[60] Kostrzewski, P., Wiaderna, A. -Brycht, Czerski, B. (1997): Biological monitoring of experimental human exposure to trimethylbenzene. - Science of the Total Environment 199: 73-81.

[61] Krizman-Matasic, I., Senta, I., Kostanjevecki, P., Ahel, M., Terzic, S. (2019): Long-term monitoring of drug consumption patterns in a large-sized European city using wastewater-based epidemiology: comparison of two sampling schemes for the assessment of multiannual trends. - Science of the Total Environment 647: 474-485.

[62] Lagoviyer, S, O., M. Schoenitz, Dreizin, E. L. (2018): Effect of process parameters on mechanochemical nitration of toluene. - Journal of Materials Science 53: 13690-13700.

[63] Larsen, P. E., Gibbons, S. M., Gilbert, J. A. (2012): Modeling microbial community structure and functional diversity across time and space. - FEMS Microbiology Letters 332: 91-98.

[64] Lauren Hayashi, M. S., Young, A., Kruger, M., Wayman, G. A., Coffinn, A. B. (2014): The effect of the aquatic contaminants bisphenol-A and PCB-95 on the zebrafish lateral line. - NeuroToxicology 46: 125-136.

[65] Li, M. T., Hao, L. L., Sheng, L., Xu, J. B. (2008): Identification and degradation characterization of hexachlorobutadiene degrading strain Serratia marcescens HL1. Bioresource Technology 99: 6878-6884.

[66] Li, Z., Hogan, K. A., Cai, C, Rieth, S. (2016): Human health effects of biphenyl: key findings and scientific issues. - Environmental Health Perspectives 124: 703-712.

[67] Licht, L. A., Isebrands, J. G. (2005): Linking phytoremediated pollutant removal to biomass economic opportunities. - Biomass \& Bioenergy 28: 203-218. 
[68] Lin, H., Gao, W., Meng, F., Liao, B.-Q., Leung, K.-T., Zhao, L., Chen, J., Hong, H. (2012): Membrane bioreactors for industrial wastewater treatment: a critical review. Critical Reviews in Environmental Science and Technology 42: 677-740.

[69] Liu, A., Ma, Y., Gunawardena, J. M. A., Egodawatta, P., Ayoko, G. A., Goonetilleke, A. (2018): Heavy metals transport pathways: The importance of atmospheric pollution contributing to stormwater pollution. - Ecotoxicology and Environmental Safety 164: 696-703.

[70] Long, S., Zhao, L., Liu, H., Li, J., Zhou, X., Liu, Y., Qiao, Z., Zhao, Y., Yang, Y. (2019): A Monte Carlo-based integrated model to optimize the cost and pollution reduction in wastewater treatment processes in a typical comprehensive industrial park in China. Science of the Total Environment 647: 1-10.

[71] Longyang, Q. (2019): Assessing the effects of climate change on water quality of plateau deep-water lake - A study case of Hongfeng Lake. - Science of the Total Environment 647: 1518-1530.

[72] Ma, W., Liu, C., Zhao, D., Guo, Y., Wang, A., Jia, K. (2015): Microbial characterization of denitrifying sulfide removal sludge using high-throughput amplicon sequencing method. - China Petroleum Processing \& Petrochemical Technology 17: 89-95.

[73] Matilda, S. C., Shanti, C. (2017): Metal induced changes in trivalent chromium resistant Alcaligenes faecalis VITSIM2. - Journal of Basic Microbiology 57(5): 402-412. https://doi.org/10.1002/jobm.201600596.

[74] Megarajan, S., Edward, L. L., Ranjan, R., Menon, M., Ghosh, S., Shettigar, V., Xavier, B. (2019): Narrow Barred Spanish Mackerel (Scomberomorus commerson) Confirmed with Leucism from East Coast of India. - Turkish Journal of Fisheries and Aquatic Sciences 19: 81-87.

[75] Mkhinini, M., Boughattas, I., Alphonse, V., Livet, A., Bousserrhine, N., Banni, M. (2019): Effect of treated wastewater irrigation in East Central region of Tunisia (Monastir governorate) on the biochemical and transcriptomic response of earthworms Eisenia andrei. - Science of the Total Environment 647: 1245-1255.

[76] Moghadam, M. S., Safaei, N., Ebrahimipour, G. H. (2016): Optimization of phenol biodegradation by efficient bacteria isolated from petrochemical effluents. - Global Journal of Environmental Science and Management-Gjesm 2: 249-256.

[77] Musa, N. M., Abdulsalam, S., Suleiman, A. D. I., Sale, A. (2015): Bioremediation of petroleum refinery wastewater effluent via augmented native microbes. - Journal of Emerging Trends in Engineering and Applied Sciences 6: 1-6.

[78] Nascimento, A. L., Souza, A. J., Maia, P. A. Andrade, Andreote, F. D., Coscione, A. R., Oliveira, F. C., Regitano, J. B. (2018): Sewage sludge microbial structures and relations to their sources, treatments, and chemical attributes. - Frontiers in Microbiology 9. https://doi.org/10.3389/fmicb.2018.01462.

[79] Navarro-Locsin, G. C., Lim, M. -Jurado. (2018): Aeroallergen sensitization and associated comorbid diseases of an adult Filipino population with allergic rhinitis. - Asia Pacific Allergy 8(3): e25.

[80] Nie, M., Zhang, W., Yan, C., Xu, W., Wu, L., Ye, Y., Hu, Y., Dong, W. (2019): Enhanced removal of organic contaminants in water by the combination of peroxymonosulfate and carbonate. - Science of the Total Environment 647: 734-743.

[81] Nijenhuis, I., Andert, J., Beck, K., Vieth, A., Kastner, M., Richnow, H. H., Diekert, G. (2004): Use of Stable Isotope Fractionation for the Assessment of Bioattenuation of Chlorinated Ethenes. - In: Verstraete, W. (ed.) Environmental Biotechnology. Taylor \& Francis, London.

[82] Nikel, P. I., Perez, D.-P., Lorenzo, V. de (2016): Pyridine nucleotide transhydrogenases enable redox balance of Pseudomonas putida during biodegradation of aromatic compounds. - Environmental Microbiology 18: 3565-3582.

[83] Nikolaivits, E., Dimarogona, M., Karagiannaki, I., Chalima, A., Fishman, A., Topakas, E. (2018): Characterization and protein engineering of a novel versatile fungal polyphenol 
oxidase with chlorophenol bioremediation potential. - Appl Environ Microbiol. DOI: 10.1128/AEM.01628-18.

[84] Nzila, A., Sankara, S., Al-Momani, M., Musa, M, M. (2018): Isolation and characterisation of bacteria degrading polycyclic aromatic hydrocarbons: phenanthrene and anthracene. - Archives of Environmental Protection 44: 12.

[85] Obi, L. U., Atagana, H. I., Adeleke, R. A. (2016): Isolation and characterisation of crude oil sludge degrading bacteria. - Springerplus 5: 1946.

[86] Ojha, A., Mishra, A. K., Vashisht, A. K. (2013): Isolation of phenol degrading bacteria from industrial waste water and their growth kinetic assay. - Journal of Pure and Applied Microbiology 7: 683-690.

[87] Otzen, M., Cyntia, P., Janssen, D. B. (2018): Characterization of the caprolactam degradation pathway in Pseudomonas jessenii using mass spectrometry-based proteomics. - Applied Microbiology and Biotechnology 102(15): 6699-6711.

[88] Oves, M., Khan, M. S., Zaidi, A. (2013): Biosorption of heavy metals by Bacillus thuringiensis strain OSM29 originating from industrial effluent contaminated north Indian soil. - Saudi Journal of Biological Sciences 20: 121-129.

[89] Panasia, G., Philipp, B. (2018): LaoABCR, a novel system for oxidation of long-chain alcohols derived from SDS and alkane degradation in Pseudomonas aeruginosa. - Appl Environ Microbiol 84. doi: 10.1128/AEM.00626-18.

[90] Peng, P., Zheng, Y., Koehorst, J. J., Schaap, P. J., Stams, A. J. M., Smidt, H., Atashgahi, S. (2017): Concurrent haloalkanoate degradation and chlorate reduction by Pseudomonas chloritidismutans AW-1(T). - Appl Environ Microbiol 83. DOI: 10.1128/AEM.0032517.

[91] Pettit, T., Irga, P. J., Torpy, F. R. (2018): Towards practical indoor air phytoremediation: A review. - Chemosphere 208: 960-974.

[92] Pugazhendi, A., Wazin, H. A., Qari, H., Basahi, J., Godon, J. J., Dhavamani, J. (2017): Biodegradation of low and high molecular weight hydrocarbons in petroleum refinery wastewater by a thermophilic bacterial consortium. - Environmental Technology 38: 2381-2391.

[93] Rafat, A., Roushandeh, A. M., Alizadeh, A., Hashemi, N. -Firouzi, Golipoor, Z. (2018): Comparison of the melatonin preconditioning efficacy between bone marrow and adipose-derived mesenchymal stem cells. - Cell Journal 20: 450-458.

[94] Raymond, R. L. (1976): Beneficial stimulation of bacteria activity in ground water containing petroleum hydrocarbon. - AICHE 73: 390-404.

[95] Ribeiro, C., Couto, C., Ribeiro, A. R., Maia, A. S., Santos, M., Tiritan, M. E., Pinto, E., Almeida, A. A. (2018): Distribution and environmental assessment of trace elements contamination of water, sediments and flora from Douro River estuary, Portugal. Science of the Total Environment 639: 1381-1393.

[96] Rodriguez-Mateus, Z., Agualimpia, B., Zafra, G. (2016): Isolation and molecular characterization of microorganisms with potential for the degradation of oil and grease from palm oil refinery wastes. - Chemical Engineering Transaction 49: 6.

[97] Rosso, F., Vanegas, S., Rodriguez, S., Pacheco, R. (2016): Prevalence and clinical course of dengue infection in elderly patients with acute febrile illness in a tertiary care hospital in Cali, Colombia. - Biomedica 36: 179-193.

[98] Sanches, S., Martins, M., Silva, A. F., Galinha, C. F., Santos, M. A., Pereira, I. A. C., Barreto, M. T. Crespo. (2017): Bioremoval of priority polycyclic aromatic hydrocarbons by a microbial community with high sorption ability. - Environmental Science and Pollution Research 24: 3550-3561.

[99] Sancho, I., Lopez, S. -Palau, Arespacochaga, N., Cortina, J. L. (2019): New concepts on carbon redirection in wastewater treatment plants: A review. - Science of the Total Environment 647: 1373-1384.

[100] Santisi, S., Cappello, S., Catalfamo, M., Mancini, G., Hassanshahian, M., Genovese, L., Giuliano, L., Yakimov, M. M. (2015): Biodegradation of crude oil by individual bacterial 
strains and a mixed bacterial consortium. - Brazilian Journal of Microbiology 46: 377387.

[101] Sarkar, J., Kazy, S. K., Gupta, A., Dutta, A., Mohapatra, B., Roy, A., Bera, P., Mitre, A., Sari, P. (2016): Biostimulation of indigenous microbial community for bioremediation of petroleum refinery sludge. - Frontiers in Microbiology 7. https://doi.org/10.3389/fmicb.2016.01407.

[102] Scoma, A., Hernandez, E. -Sanabria, Lacoere, T., Junca, H., Boon, N., Pieper, D. H., Vilchez-Vargas, R. (2017): Primers: Bacterial Genes Encoding Enzymes for Aerobic Hydrocarbon Degradation. - In: McGenity, T. J., Timmis, K. N., Nogales, B. (eds.) Hydrocarbon and Lipid Microbiology Protocols: Primers. Springer, Berlin, Heidelberg, pp. 23-37.

[103] Serio, F., Miglietta, P. P., Lamastra, L., Ficocelli, S., Intini, F., De Leo, F., De Donno, A. (2018): Ground water nitrate contamination and agricultural land use: A grey water footprint perspective in Southern Apulia Region (Italy). - Science of the Total Environment 645: 1425-1431.

[104] Shi, Y., Zhang, J., He, J., Liu, D., Meng, X., Huang, T., He, H. (2019): A method of detecting two tumor markers (p-hydroxybenzoic acid and p-cresol) in human urine using a porous magnetic < beta > -cyclodextrine polymer as solid phase extractant, an alternative for early gastric cancer diagnosis. - Talanta 191: 133-140.

[105] Silva, C. C., Hayden, H., Sawbridge, T., Mele, P., Kruger, R. H., Rodrigues, M. V. N., Costa, G. G. L., Vidal, R. O., Sousa, M. P., Torres, A. P. R., Santiago, V. M. J., Oliveira, V. M. (2012): Phylogenetic and functional diversity of metagenomic libraries of phenol degrading sludge from petroleum refinery wastewater treatment system. - Amb Express 2. https://doi.org/10.1186/2191-0855-2-18.

[106] Singh, A., Kumar, V., Srivastava, J. N. (2013): Assessment of bioremediation of oil and phenol contents in refinery waste water via bacterial consortium. - Journal of Petroleum \& Environmental Biotechnology 4: 145. DOI: 10.4172/2157-7463.1000145.

[107] Singh, G., Kumari, B., Sinam, G., Kriti, Kumar, N., Mallick, S. (2018): Fluoride distribution and contamination in the water, soil and plants continuum and its remedial technologies, an Indian perspective - a review. - Environmental Pollution 239: 95-108.

[108] Sousa, D. A., Costa, A. I., Alexandre, M. R., Prata, J. V. (2019): How an environmental issue could turn into useful high-valued products: The olive mill wastewater case. Science of the Total Environment 647: 1097-1105.

[109] Staehelin, P. M., Valerio, A., Guelli Ulson de Souza, S. M. d. A., da Silva, A., Borges Valle, J. A., Ulson de Souza, A. A. (2018): Benzene and toluene removal from synthetic automotive gasoline by mono and bicomponent adsorption process. - Fuel 231: 45-52.

[110] Tahtouh, J., Mohtar R., Assi A., Schwab P., Jantrania A., Deng Y., Munster C. (2019): Impact of brackish groundwater and treated wastewater on soil chemical and mineralogical properties. - Science of the Total Environment 647: 99-109.

[111] Tang, J. (2011): Microbial metabolomics. - Current Genomics 12: 391-403.

[112] Tang, M., Dou, X., Tian, Z., Yang, M., Zhang, Y. (2019): Enhanced hydrolysis of streptomycin from production wastewater using $\mathrm{CaO} / \mathrm{MgO}$ solid base catalysts. Chemical Engineering Journal 355: 586-593.

[113] Toshchakov, S. V., Kublanov, I. V., Messina, E., Yakimov, M. M., Golyshin, P. N. (2017): Genomic Analysis of Pure Cultures and Communities. - In: McGenity T. J., Timmis K. N., Nogales B. (eds.) Hydrocarbon and Lipid Microbiology Protocols: Genetic, Genomic and System Analyses of Communities. Springer, Berlin, Heidelberg, pp. 5-27.

[114] Vecchio, A., Finoli, C., Di Simine, D., Andreoni, V. (1998): Heavy metal biosorption by bacterial cells. - Fresenius' Journal of Analytical Chemistry 361: 338-342.

[115] Vendramel, S., Bassin, J. P., Dezotti, M., Sant'Anna, G. L. Jr. (2015): Treatment of petroleum refinery wastewater containing heavily polluting substances in an aerobic submerged fixed-bed reactor. - Environmental Technology 36: 2052-2059. 
[116] Vinaixa, M., Schymanski, E. L., Neumann, S., Navarro, M., Salek, R. M., Yanes, O. (2016): Mass spectral databases for LC/MS- and GC/MS-based metabolomics: State of the field and future prospects. - TrAC Trends in Analytical Chemistry 78: 23-35.

[117] Wang, L., Lv, Q., An, M., Liu, Z., Song, Y., Zhou, Y., Li, J., Xu, J. (2018): Identification of toxic substances in phenol-acetone wastewater on activated sludge and selective toxicity removal performance with ferrous pretreatment. - Environmental Science and Pollution Research 25: 19628-19634.

[118] Wang, M.-Z., Lai, B.-M., Dandekar, A. A., Yang, Y.-S., Li, N., Yin, J., Shen, D.-S. (2017): Nitrogen source stabilization of quorum sensing in the Pseudomonas aeruginosa bioaugmentation strain SD-1. - Appl Environ Microbiol 83. DOI: 10.1128/AEM.0087017.

[119] Williams, M., Kookana, R. S., Mehta, A., Yadav, S. K., Tailor, B. L., Maheshwari, B. (2019): Emerging contaminants in a river receiving untreated wastewater from an Indian urban centre. - Science of the Total Environment 647: 1256-1265.

[120] Yalcin, E., Cavusoglu, K., Ozen, E. (2011): Hydrocarbon degradation by a new Pseudomonas sp., strain RW-II, with polycationic surfactant to modify the cell hydrophobicity. - Environmental Technology 32: 1743-1747.

[121] Yan, H. Y., Xiao, M., Zhang, Z. Z., Li, J. Q., Shi, B. Q. (2014): Remediation of oilfield wastewater produced from alkaline/surfactant/polymer flooding by using a combination of coagulation and bioaugmentation. - Petroleum Science and Technology 32: 15211528.

[122] Yan, J., Xu, L., Wei, X. (2013): Biodegradation Characteristics and Bioaugmentation Potential of an Efficient O-Cresol-Degrading Strain Isolated from Petrochemical Sewage Treatment Plant. - In: Zhao J., Iranpour R., Li X., Jin B. (eds.) Advances in Environmental Technologies. Trans Tech Publications, Beck, Munich, pp. 264-268.

[123] Zhang, R.-C., Xu, X.-J., Chen, C., Shao, B., Zhou, X., Yuan, Y., Lee, D.-J., Ren, N.-Q. (2019): Bioreactor performance and microbial community analysis of autotrophic denitrification under micro-aerobic condition. - Science of the Total Environment 647: 914-922.

[124] Zhang, Y., Tian, Y., Zhang, Z., Lin, S. (2018): Experimental and numerical study of cavitating flow with suction in a mixing reactor for water treatment. - Chemical Engineering Journal 353: 796-804.

[125] Zhao, Y., Liu, R., Awe, O. W., Yang, Y., Shen, C. (2018): Acceptability of land application of alum-based water treatment residuals - An explicit and comprehensive review. - Chemical Engineering Journal 353: 717-726. 